\title{
Becoming a New Citizen in an Immigration Country: Turks in Australia and Sweden and Some Comparative Implications ${ }^{1}$
}

\author{
Ahmet Icduygu*
}

\section{INTRODUCTION}

Large-scale international migration to migrant receiving democratic states has made the issue of access to citizenship and to citizenship rights a phenomenon of increasing global importance. The status of millions of migrants around the world today is socially and politically anomalous. International migration since World War II has led to the emergence of large groups of foreign citizens who, for all intents and purposes, are permanent residents but cannot fully benefit from the various civil, political and social rights granted to citizens of the state. ${ }^{2}$ Issues of access to citizenship and to citizenship rights, and the implied potential for conflict between nationals and aliens in migrant receiving countries, have gained widespread attention in migration literature since the mid-1980s (Hammar, 1985, 1986, 1990; Tung, 1985; DeSipio, 1987; Brubaker, 1989, 1990; Miller, 1989; Silverman, 1991, 1992; Hintjens, 1992). While concern has been particularly strong in Europe, it is also apparent in traditional migrant receiving countries such as the United States, Canada and Australia. Given the importance of citizenship as a key to participation in a nation's political life, and as a symbol of commitment to the future of a nation state, international migration is a challenge to both theory and practice of governance in migrant receiving democratic societies. As the world and the nation states in the international system settle into a new era towards the turn of the century, some interesting aspects of further analytical inquiry on the immigration and citizenship debate have emerged, one of which is the demand for a better understanding of immigrants' perceptions and attitudes concerning their own position in the process of access to citizenship and to citizenship rights.

* Department of Political Science and Public Administration, Bilkent University, Ankara, Turkey. 
Several studies on the immigration and citizenship debate (DeSipio, 1987; Evans, 1988; Yang, 1994) have emphasized that research in this field is not fully developed. A common conclusion is that the main perspective of many citizenship studies has generally ignored immigrants' perceptions and attitudes concerning their own position; instead, there has been a focus on the interplay of nation state and citizenship rights as taken into consideration by the receiving society. ${ }^{3}$ Such studies generally do not examine the meaning that citizenship might have, nor do they examine the relationship between citizenship and the migration, settlement and adjustment processes, as experienced by migrants. In addition, migrants are generally viewed as a "free-will, rational, political and economic" category; the experiences of all migrants are assumed to be uniform, if they are discussed at all. For example, it has been argued that an immigrant's decision to become a citizen in the receiving country is an indication of "belonging to, and identification with, the nation, its people, its values and its institutions" (Macphee, 1982: 1), or a "celebration of a commitment which is nurtured by the gradual growth of social, emotional and financial investments" (Evans, 1988: 244). The common perspective of this macro approach to citizenship and immigration often neglects the dynamic nature of the adaptation process and so contributes to an ongoing inconclusiveness. As noted by Yang (1994: 449-451), these approaches raise numerous questions which can be answered only by locating and conceptualizing the position of individual migrants in the totality of the migratory context.

This article explores the mechanism and dynamics of the context in which Turkish migrants living in Australia and Sweden change their citizenship. It addresses costs, benefits and meaning of citizenship which are of most immediate concern in an immigrant's decision to take out citizenship in the receiving country.

\section{BACKGROUND}

The concept of "life strategies" used in sociological and demographic literature implies adaptation of one's life and life style to different environmental conditions (Crow, 1989; Morgan, 1989). Indeed, each major event in an immigrant's life, for instance access to citizenship, involves a process of adaptation, alone or with others, that is related to various factors, including economic and social conditions and expected outcomes of the events. The successive steps of significant events can be seen as plans and actions made sequentially, thus constituting a life strategy. For instance, in addressing the question whether there exist return migration and/or settlement strategies by so-called temporary migrants in a host country, the author (Icduygu, 1993: 80-82) found that 
there were four successive strategic steps in the migratory and settlement process that form the cornerstones of the migrant's changing settlement intention from temporary stay to permanent. First, visiting the homeland; second, purchasing a house in the homeland; third, purchasing a house in the receiving country; and finally deciding to stay permanently in the receiving country. From a similar perspective, the question posed for the present article is what are the strategic implications of changing citizenship for immigrants within the overall context of the migration and settlement process?

These strategic implications depend on the nature and type of migration process, on whether the receiving society is permanent-settlement or temporary-settlement oriented, the documented or undocumented status of the migrant, the qualifications and position of the migrant in the labour market, duration of stay, and kinship or other informal ties that the immigrant maintains in his/her host and origin country. While the discussion here on the naturalization process of Turkish immigrants living in Australia and Sweden does not take into consideration the variation of factors within the context of different types of migration and groups of migrants, most of the observations have some relevance to the immigrant's access to citizenship rights in the receiving country.

Comparison of the experiences of Turkish immigrants in Australia and Sweden should be viewed within the different historical and social contexts of migratory flows to the two countries. ${ }^{4}$ Since the early 1960s, hundreds of thousands of Turks have gone abroad, particularly to Germany, to sell their labour. Only a small proportion (estimated 1 per cent) emigrated to Australia, and in a context which was considered by the Australian government (although not by many Turkish migrants) to be permanent settlement. There was also a minor flow (estimated 1 per cent) to Sweden where, unlike some other European countries such as Germany, Switzerland, the Netherlands and Denmark, immigration policy recognized, but did not necessarily intend, that immigration could be permanent. Most of the Turkish immigrants who arrived in Australia and Sweden expected to be "guests" for a limited period of employment rather than to settle, as was happening with the guest worker scheme in Germany.

At no time has the guest worker notion been a part of Australia's immigration policy (Foster and Stockley, 1984: 28). Australia expects permanent immigrants to become citizens without delay and that children born on its territory should therefore automatically become citizens according to the jus solis principle. ${ }^{5}$ On the basis of current regulations, once a person born overseas has stayed in Australia on a permanent resident visa for at least two years, he or she is eligible to become an 
Australian citizen. Naturalization conditions are limited, the procedures are simple and the costs are low. Almost all immigrants of good conduct, having fulfilled the residence requirement of two years, are granted rights to citizenship.

Swedish immigration policy, on the other hand, has never had the objective that immigration should be permanent or for that matter not permanent (Hammar, 1985: 48-49). Sweden grants citizenship mainly according to the blood principle ${ }^{6}$ and does not encourage immigrants to become Swedish citizens. In Australia naturalization is generally considered to be an immigrant's right; in Sweden it is granted at the state's discretion. Compared with the other cases in Europe, Swedish policy towards citizenship may be considered liberal, but compared with Australia's policy, it is certainly protectionist. Immigrants in Sweden are required to have five years' residence before applying for citizenship. Naturalization requirements are much more demanding and the applicant must not only be an able person deserving to become a fellow citizen, but also prove his or her willingness for integration into the nation's language and culture.

\section{THE MELBOURNE AND STOCKHOLM SURVEYS}

Information concerning changing citizenship strategies by immigrants was obtained as part of surveys undertaken on the migration, settlement and integration experiences of Turkish immigrants in Melbourne, Australia and of those in Stockholm, Sweden. The data were collected during the late 1980 s and early 1990 s.

The Australian data were collected by the author between 1987 and 1990 from interviews with 276 immigrants in Melbourne, a city which has been a primary destination for more than half the Turkish migrants to Australia. Respondents were selected through a multistage sampling basis of the 1981 Census maps. All respondents were migrants who had been born in Turkey, were of Turkish ethnic origin and were aged 18 years and over on arrival in Australia.

Basic characteristics of Melbourne's Turkish immigrant population are as follows: 96 females per 100 males; average age at arrival 29 years; median level of education 8 years; 70 per cent were married and 17 per cent never married. Economic motivation was the main reason for their movement to Australia: many aimed to bolster their precarious middleclass standing in Turkey by accumulating savings which would be invested back home. The median period of residence was 14 years. The immigrant population was neither predominantly rural nor from the 
ranks of the chronically unemployed or underemployed. Eighty-nine per cent of males and one-third of the females had been employed prior to migration; 97 per cent of the males and 85 per cent of females had worked for wages at some time during their residence in Australia, and 64 per cent of the males and 38 per cent of the females were in the labour force when interviewed. More than half the currently employed immigrants were working as tradespersons, production process workers or labourers. The majority of the others held jobs in four occupational groups: professionals (16 per cent), sales workers (9 per cent), clerical workers ( 8 per cent) and service and recreation workers ( 7 per cent). The majority of the early migrants were aged 45 to 50 years, and many had already withdrawn from the paid workforce. One quarter of the interviewed migrants were receiving pensions and the average age of these pensioners was 49 years.

The Swedish survey data were obtained in 1991 from interviews with 297 immigrants in Stockholm (where live almost three-fifths of Sweden's Turkish community) concerning their migration, settlement and integration. The sampling procedure utilized information from the Register of the Total Population (RTB) kept by Statistics Sweden (SCB). The sample was achieved by the web technique, taking representativeness into consideration on the basis of age, sex, length of residence and area of residence demonstrated in the 1990 Registration figures. As with the Melbourne survey, respondents were selected from migrants who had been born in Turkey, were aged 18 years and over on arrival in Sweden and were of Turkish ethnic origin.

Males comprised 59 per cent of the Swedish immigrant population surveyed, average age at arrival was 24 years and the median level of education was 5 years. Immigrants were predominantly from rural areas. Many came to Sweden to work and save money as quickly as possible with the aim of returning to Turkey. The median period of residence was 16 years. Seventy three per cent of respondents were married, 13 per cent had never married and 14 per cent were divorced or separated. While only 5 per cent of the females and 75 per cent of the males had been employed prior to emigration, 93 per cent of the males and 41 per cent of the females had worked for wages at some time since moving to Sweden. At time of the survey, 77 per cent of the males and 29 per cent of the females were in the labour force. Most respondents (male and female) in the work force were unskilled labourers ( 28 per cent), semiskilled tradespersons ( 20 per cent), and service workers ( 18 per cent). A parallel development to the case of Turkish immigrants in Melboume was that a large proportion of the sampled first generation Turkish immigrants in Stockholm had withdrawn from paid employment permanently, although they were still in middle age. 


\section{FINDINGS}

As already noted, despite the fact that Australian immigration policy emphasizes permanent settlement and Swedish immigration policy accepts the likelihood of both permanent and temporary settlement, the majority of Turkish migrants in both countries had, on arrival, no intention of permanent settlement. Although most Turkish migrants tended to regard their stay in Australia and Sweden as temporary, only a few had actually returned to Turkey. This suggests that while migrants' willingness to go back to Turkey remains alive in their minds, Turkish settlement in both countries has been characterized by a transition from temporary sojourn to unintended settlement (Icduygu, 1993: 76; 1994: 82). There is no doubt that becoming a citizen in the host country plays a very important strategic role within the context of this transition. When asked when and why they decided to become a citizen, more than two-thirds of those interviewed in Melbourne and over one half of those interviewed in Stockholm stated that their decisions on citizenship were related to the their decisions concerning permanent settlement.

The Melbourne survey indicates that among those who were eligible to become Australian citizens 63 per cent had taken out Australian citizenship at the time of interview in 1987 (Table 1, page 268). Apart from those who were already Australian citizens, 15 per cent declared their intentions to become citizens and another 8 per cent stated that they had already applied for citizenship. The Stockholm survey indicated that the proportion of Turkish-born persons with Swedish citizenship was 39 per cent in 1991 (Table 2, page 268); only 3 per cent stated intentions to become citizens, and only 1 per cent indicated that they had already applied for citizenship. Despite the time gap between these two surveys, the higher figures for the Melbourne survey were due mainly to the differences between the immigration, settlement and consequent citizenship policies in Australia and Sweden. Those who were exposed to the pronounced permanent intentions of Australian immigration would probably adopt the idea of permanent settlement and naturalization far more readily than those who were subject to Swedish immigration and settlement policies, with their lack of clear objectives concerning whether immigration should or should not be permanent and whether immigrants should or should not take out Swedish citizenship.

Only 13 per cent of Australian respondents indicated that they had no intention of taking out citizenship; 45 per cent of these had arrived in Australia between 1968 and 1974 while the remaining 55 per cent were the late migrants who arrived in Australia between 1975 and 1985. Nearly three-fifths of the respondents in Sweden stated that they had no intention of becoming Swedish citizens: 90 per cent of these had arrived in Sweden between 1965 to 1974 . The Australian data indicate a positive relation- 
ship between taking out citizenship and duration of residence, a correlation not confirmed by the findings of the Stockholm Survey. Over 70 per cent of the migrants who arrived in Australia between 1968 and 1974 held Australian citizenship, the figures for those who arrived between 1975 and 1980 and between 1981 and 1985 were 64 per cent and 28 per cent respectively. Contrasting with the Australian figures, only 35 per cent of those who arrived in Sweden during the period 1965 and 1974 held Swedish citizenship, while the figures for those who arrived between 1975 and 1980, and for those who arrived between 1981 and 1985, rose to 56 per cent and 59 per cent respectively. Turkish immigrants who entered Sweden in the later period were more likely to become citizens than those who entered Australia during the same period. The mixed results on impact of duration of residence on the likelihood of citizenship acquisition were due partly to the fact that characteristics of the two migrant populations were different. For example, being village-born and having limited formal education were more characteristic of early Turkish immigrants in Sweden than those in Australia. Village-born immigrants with limited formal education were less likely to become citizens than those who were city-born with high levels of schooling. Similarly, later immigrants in Sweden were mostly refugees and therefore more likely to become citizens than early economic immigrants.

While evidence from the Melbourne and Stockholm surveys gave mixed and puzzling conclusions on the importance of duration of residence as a cause of citizenship acquisition, the effects of the other selected characteristics of sampled immigrants are not contradictory. Indeed, consistency characterizes the results from the two surveys. Male immigrants were more likely to become citizens than females. Access to citizenship varied according to age at arrival, birthplace, schooling, occupation and language skill (Table 3, page 269). Those who migrated (to both countries) at a younger age were more likely to become citizens than those who were older. Similarly, urban background, higher levels of schooling, white-collar occupation and high levels of language skill were positively related to acquisition of citizenship.

The surveys also showed that pragmatic considerations were given as important factors affecting their decisions to become, or intention to become, citizens (Table 4, page 270). Apart from only three per cent of respondents in Stockholm and one tenth of those in Melbourne who mentioned the advantages of travelling with passports of the receiving states, more than one-third of the sampled immigrants in Stockholm and nearly a quarter of those in Melbourne said that citizenship provided opportunity to live in both the host and home countries without having visa and residence permit problems. Citizenship also gave them the right to seek permanent positions in the public and government services. Many believed that job opportunities would be more abundant not only 
for themselves but most importantly for their children. One quarter of the respondents in Stockholm and 13 per cent of those in Melbourne gave "making the future for our children more easy and comfortable in the receiving societies" as their reason for choosing Australian or Swedish citizenship.

For one-fifth of respondents in Stockholm and over two-fifths in Melbourne the reasons for becoming citizens included normative and moral as well as pragmatic motivations. While 21 per cent of the Melbourne respondents felt that it was proper that they should become citizens after deciding on permanent residence, another 21 per cent indicated that they would be able to utilize the various rights of citizenship such as voting. In Sweden, the corresponding figures were 5 and 15 per cent respectively. Meanwhile, many respondents pointed out that Turkey's decision in 1981 to allow dual citizenship had been a stimulus for their decision. ${ }^{7}$

Hulusi (a 49-year-old male in Melbourne):

Until 1981 I never thought about citizenship. But when the Turkish government allowed us to take out Australian citizenship, every Turkish migrant started to think about it... We were living here for a long time, so to become an Australian citizen was something good, for example voting... If you have an Australian passport you can travel around the world without having any visa problems... You can have a good job if you are a citizen here in Australia... So citizenship is a practical remedy for our problems... If becoming Australian citizens was something bad, why would the Turkish government give permission to us for dual citizenship... (author's italics) [R. No: 0601061]

Mahmut (a 41-year-old male in Stockholm):

Since I decided to live here in Sweden, since I work here, since my principal livelihood is Sweden, I thought that I should participate in every aspect of life here, and I applied to take out Swedish citizenship... I am doing a good thing for me, and for Sweden... But $\mathrm{I}$ am not doing anything against Turkey, I love Turkey which is my homeland... the Turkish government encourages us to have dual citizenship which is good for us... This is a very practical solution... If you are becoming a Swedish citizen this means that you are making the future of your children easy and comfortable in Sweden. (author's italics) [R. No: 0103051]

While those who had become citizens of the receiving states, or intended to do so, emphasized that pragmatic considerations had played an important role in their decisions, among those who indicated that they did not intend becoming citizens were a large proportion who also gave pragmatic reasons to explain their attitudes (Table 4). A third in Melbourne, and a quarter in Stockholm, believed that they would not obtain any benefit from naturalization in the host country; and 23 per cent in Melbourne and 21 per cent in Stockholm felt that they might lose some of their rights in Turkey, especially regarding property owned there. 
In this context, some complained that dual citizenship regulations in Turkey were unclear and mentioned rumours about confiscation of properties if they took another citizenship. More than a fifth of respondents in Australia and nearly a third of those in Sweden said that they were not willing to become citizens because they intended to return to Turkey permanently. For a fifth both in Melbourne and Stockholm, the main reason for refusing citizenship rights was that becoming citizens in these countries would be inappropriate because they considered themselves Turkish rather than Australian or Swedish.

\section{CONCLUSIONS}

Because the present study has focused on the experiences of Turkish immigrants in Australia and Sweden, it is difficult to argue that the findings are relevant to other immigrant groups and other countries. However, when compared with several previous studies, the evidence here is essentially complementary. A contradictory negative relation between the longer duration of residence and becoming a citizen in Sweden when compared with the importance of this duration in the case of becoming an Australian citizen, justifies further research on the extent to which becoming a citizen is a product of duration of residence or other social and demographic characteristics, or a combination of both.

Consistent with previous research, the evidence suggests that decisions on citizenship are made in the context of a life strategy. Many immigrants relates their decisions on citizenship to their decisions on settlement within the context of temporariness versus permanence. In addition to the importance of duration of residence (which implies puzzling evidence), a migrant's gender, age at arrival, birthplace, schooling, occupation, and language skill exert a strong influence upon his/her decision to become a citizen.

Whether differences between the Australian and Swedish cases is a result of historical, social, and economic contexts of migratory processes to the two countries, or of different characteristics of the Turkish immigrant populations, or a combination of these factors, is difficult to resolve. Any systematic and comprehensive attempt to understand this complexity is beyond the purpose of this article. Although the distinction between the two cases is apparent, similar patterns exist among immigrants in both Melbourne and Stockholm with respect to their perceptions and attitudes towards processes of settlement and access to citizenship. A feeling of temporariness is more notable among the Turks in Sweden than among those in Australia, but for the vast majority in both countries, the issue of access to citizenship is mainly a matter of pragmatic choice rather than normative and moral commitment. 


\section{NOTES}

1. The study is based on data collected by the author in Australia and Sweden between 1987 and 1992. Data collection in Melbourne was made possible by a grant from the Research School of Social Sciences at the Australian National University, Canberra, in 1987-90. The Stockholm study was supported by a grant from the Swedish Institute, Stockholm in 1991-92. Part of this article was presented at the International Conference on Global Politics, Nottingham, July 1994.

2. It is estimated that about eighteen million persons residing in Western Europe in the early 1990 s were not entitled to citizen status in the countries where they lived because they were regarded as immigrants. Similarly, more than two-fifths of overseas-born residents in Australia who were eligible for Australian citizenship had not become citizens in the early 1990s.

3. As argued elsewhere by the author, the consequences of international migration policies and practices of citizenship are experienced at three levels: that of migrants themselves, the country they enter, and the country they leave. The main perspective of many studies of citizenship and immigration has been at the second level. Little attention has been paid to the first and third levels (Icduygu, 1994).

4. For detailed information on the migration and settlement characteristics of Turks in Australia and Sweden, see Icduygu (1993,1994).

5. While states such as the United States, Canada and Australia adhere to the soil principle ( $j u s$ soli) in which they grant citizenship to all persons born in their territory, others, mainly West and North European countries, adopt the blood principle (jus sanguinis) in which people inherit their parents' citizenship (Hammar, 1990).

6. See note 5 .

7. These quotations were drawn from the transcript of interviews with Turkish immigrants in Melbourne and Stockholm. The names of respondents used in the quotes are not their own. A seven digit identification number was given to each interviewed respondent.

\section{REFERENCES}

Brubaker, W.R.

1989 Immigration and the Politics of Citizenship in Europe and North America, German Marshall Fund of the United States, Lanham.

1990 "Immigration, citizenship, and the nation-state in France and

Crow, G. Germany", International Sociology, 5(4): 379-407.

1989 "The use of the concept of strategy in recent sociological literature", Sociology, 23: 1-24.

DeSipio, L.

1987 "Social science literature and the naturalization process", International Migration Review, 21(2): 390-405. 
Evans, M.D.R.

1988 "Choosing to be a citizen", International Migration Review , 22(2): 243-263.

Foster, L., and D. Stockley

1984 Multiculturalism: The Changing Australian Paradigm, Multilingual Matters, Clevedon.

Hammar, T.

1985 European Immigration Policy, Cambridge University Press, Cambridge.

1986 "Citizenship: Membership of a nation and of a state", International Migration, 24(4): 735-748.

1990 Democracy and the Nation State, Avebury, Aldershot.

Hintjens, H.M.

1992 "Immigration and citizenship debates: Reflections on ten common themes", International Migration, 30(1): 5-16.

Icduygu, A.

1993 "Temporariness versus permanence: Changing nature of the Turkish immigrant settlements in Australia and Sweden", paper presented at the 22nd General Conference of the International Union for the Scientific Study of Population, 24 August - 1 September, Montreal.

1994 "Facing changes and making choices: Unintended Turkish immigrant settlement in Australia", International Migration, 32(1): 71-93.

Macphee, I.M.

1982 “Australian citizenship", Parliamentary Debates, Canberra.

Miller, M.J.

1989 "Dual citizenship: A European norm?", International Migration Review, 23(4): 945-950.

Morgan, D.

1989 "Strategies and sociologists: A comment on Crow", Sociology, 23: 25-29.

Silverman, $\mathbf{M}$.

1991 "Citizenship and the nation-state in France", Ethnic and Racial Studies, 14(3): 333-349.

1992 Deconstructing the Nation, Routledge, London.

Tung, R.K.

1985 "Voting rights for alien residents - who wants it?", International Migration Review, 19(3): 451-457.

Yang, P.Q.

1994 "Explaining immigration naturalization", International Migration Review, 28(3): 449-477. 

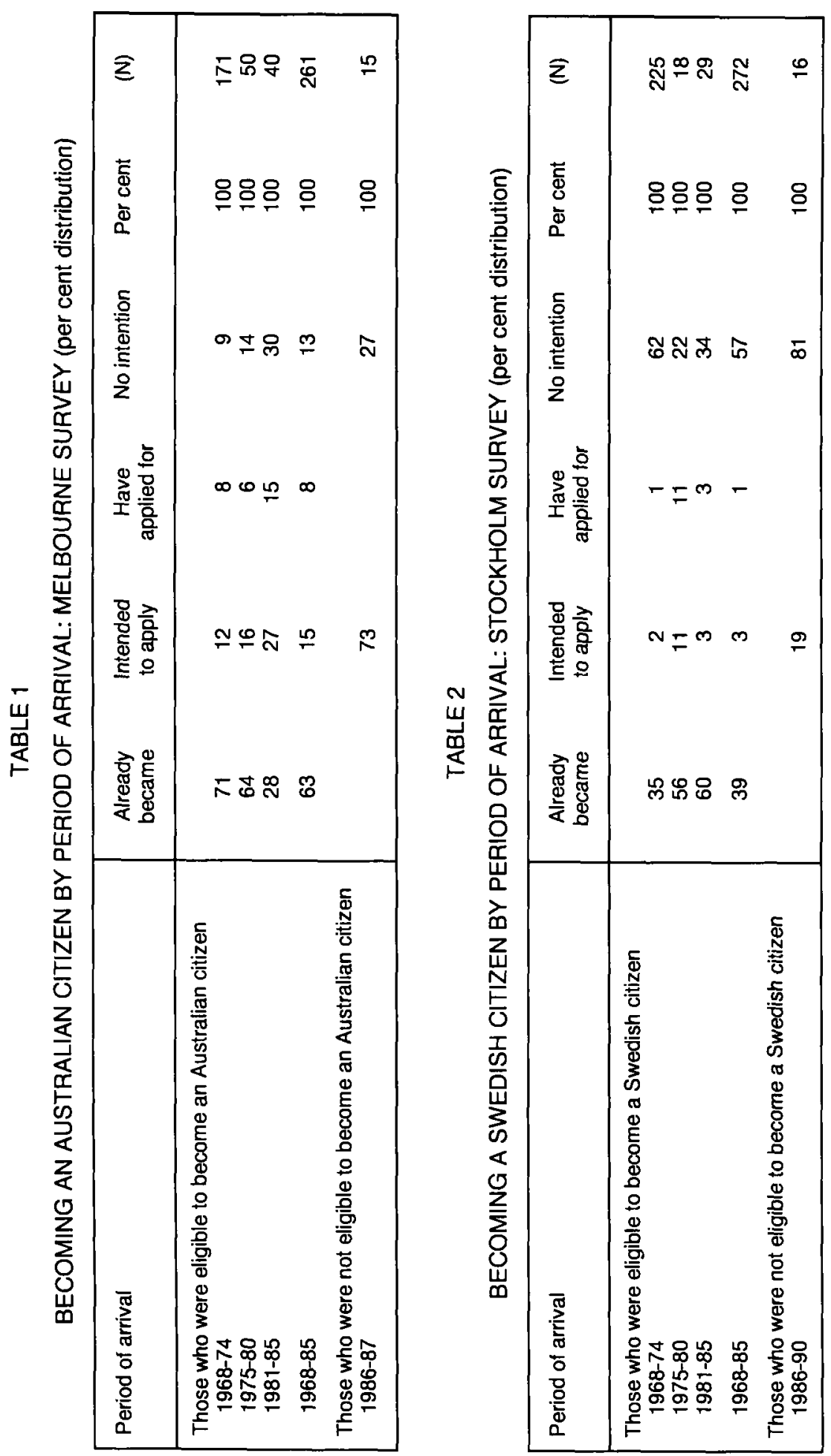
TABLE 3

REASONS FOR TAKING OR NOT TAKING CITIZENSHIP:

MELBOURNE AND STOCKHOLM SURVEYS (per cent distribution)

\begin{tabular}{|c|c|c|}
\hline Reasons & \multicolumn{2}{|c|}{ Percentage } \\
\hline Those who had taken citizenship or intended to take it & & \\
\hline Taking a decision of permanent settlement & 21 & 5 \\
\hline $\begin{array}{l}\text { To be able to use the citizenship rights } \\
\text { in the country where they live, such as voting }\end{array}$ & 21 & 15 \\
\hline $\begin{array}{l}\text { To make the future of their children easy } \\
\text { and comfortable in the receiving country }\end{array}$ & 13 & 25 \\
\hline To have better job opportunities & 7 & 14 \\
\hline $\begin{array}{l}\text { To be able to live in both receiving and sending } \\
\text { countries without having visa problems }\end{array}$ & 23 & 34 \\
\hline $\begin{array}{l}\text { To be able to travel around the world without having } \\
\text { visa problems }\end{array}$ & 9 & 3 \\
\hline Others & 6 & 4 \\
\hline (N) & $\begin{array}{l}100 \\
237\end{array}$ & $\begin{array}{l}100 \\
131\end{array}$ \\
\hline Those who had no intention of taking citizenship & & \\
\hline No benefit from it & 33 & 25 \\
\hline Because intending to go back home permanently & 21 & 32 \\
\hline Feeling of forfeiting some rights in Turkey & 23 & 21 \\
\hline $\begin{array}{l}\text { Feeling of being a Turk rather than an Australian } \\
\text { or Swede }\end{array}$ & 18 & 20 \\
\hline Others & 5 & 2 \\
\hline (N) & $\begin{array}{r}100 \\
39\end{array}$ & $\begin{array}{l}100 \\
167\end{array}$ \\
\hline
\end{tabular}


TABLE 4

CHARACTERISTICS OF MIGRANTS WHO HAD TAKEN OUT CITIZENSHIP: MELBOURNE AND STOCKHOLM SURVEYS

\begin{tabular}{|l|cc|}
\hline Characteristics & Australian citizen & Swedish citizen \\
\hline Sex & & \\
Male & 71 & 43 \\
Female & 55 & 28 \\
Age at arrival & & \\
18-29 & 69 & 48 \\
30-39 & 60 & 42 \\
$40+$ & 59 & 35 \\
Birthplace & & \\
City & 65 & 48 \\
Town & 63 & 40 \\
Village & 59 & 28 \\
Schooling & & 25 \\
No schooling & 39 & 36 \\
1-5 years & 49 & 48 \\
6-11 years & 69 & 39 \\
12+ years & 53 & \\
Occupation & & 41 \\
White-collar & 73 & 35 \\
Blue-collar & 58 & \\
Duration of residence & & 46 \\
0-4 years & 48 & 33 \\
5-9 years & 45 & 24 \\
10+ years & 56 & \\
English (or Swedish) & 69 & \\
speaking ability & & \\
Not at all/Not well & & \\
Well & & \\
Quite well/Very well & & \\
\hline
\end{tabular}




\section{ACQUERIR UNE NOUVELLE CITOYENNETE DANS UN PAYS D'IMMIGRATION : LES TURCS EN AUSTRALIE ET EN SUEDE; QUELQUES CONSEQUENCES COMPARATIVES}

Cette étude, qui se fonde sur les renseignements foumis par des immigrés turcs en Australie et en Suède, met l'accent sur les perceptions et les attitudes relatives à l'accès à la citoyenneté et aux droits y afférents. Si les résultats des enquêtes menées auprès des immigrés turcs à Melbourne et à Stockholm ont débouché sur des conclusions hétérogènes et quelque peu étonnantes quant à l'importance de la durée de résidence dans la propension des immigrés à acquérir la citoyenneté du pays d'accueil, les effets des autres caractéristiques parmi l'échantillon d'immigrés étudié n'ont pas révélé de résultats contradictoires. Les hommes se montrent plus enclins à acquérir la citoyenneté que les femmes. Mise à part les variations tenant au sexe, le schéma d'accession à la citoyenneté varie considérablement selon l'âge des immigrés à leur arrivée, leur lieu de naissance, leur éducation, leur profession et leurs aptitudes linguistiques. Les personnes ayant immigré dans l'un des deux pays alors qu'elles étaient encore jeunes sont apparues plus susceptibles de demander la citoyenneté que celles ayant immigré à un âge plus avancé. De même, la provenance d'un milieu urbain, une éducation de bon niveau, un métier intellectuel et de bonnes connaissances linguistiques apparaissent comme autant de facteurs susceptibles de pousser à l'acquisition de la citoyenneté du pays d'accueil.

Il n'est pas facile de dire si les écarts que révèlent les deux enquêtes résultent des contextes historiques, sociaux et économiques des processus migratoires vers ces deux pays, ou des différentes caractéristiques des populations d'immigrés turcs, ou encore d'une combinaison de ces différents facteurs. Les conclusions surprenantes auxquelles aboutit l'étude quant à l'importance que revêt la durée de résidence en tant que motivation pour l'acquisition de la citoyenneté pourraient être le reflet de cette complexité. Si la distinction entre les deux cas d'étude est apparente, on constate une similitude parmi les immigrés de Melbourne et de Stockholm en ce qui concerne leur perception et leurs attitudes propres face aux processus d'établissement et d'accession à la citoyenneté. On note également que les immigrés turcs de Suède ressentent davantage le caractère temporaire de leur situation que leurs homologues d'Australie, mais pour la grande majorité de ces deux populations d'immigrés, la question de l'accession à la citoyenneté est avant tout un choix pragmatique à faire, plutôt qu'un engagement moral ou une démarche de normalisation. 


\section{CONVERTIRSE EN CIUDADANO DEL PAIS \\ DE INMIGRACION: LOS TURCOS EN AUSTRALIA Y SUECIA Y ALGUNAS REPERCUSIONES COMPARATIVAS}

Este estudio, basado en la información proporcionada por los inmigrantes turcos residentes en Australia y Suecia, se centra en las percepciones y actitudes relativas a la solicitud de ciudadanía y a los derechos de los ciudadanos. Si bien los resultados de las encuestas con los inmigrantes turcos en Melbourne y Estocolmo condujeron a conclusiones mixtas y desconcertantes en cuanto a la importancia de la duración de residencia de los inmigrantes como motivo que les conduce a solicitar la ciudadanía, los efectos de otras características escogidas en la muestra de inmigrantes no reflejan resultados contradictorios. Los hombres tienen más probabilidades de solicitar la ciudadanía que las mujeres. Aparte de las variaciones basadas en el género, el patrón de acceso a la ciudadanía varía considerablemente según la edad que tenía el inmigrante al llegar al país, el lugar de nacimiento, la formación escolar, la profesión y los conocimientos del idioma. Aquellos que emigraron a ambos países cuando eran muy jóvenes tienen mayores probabilidades de obtener la ciudadanía que aquellos que lo hicieron cuando eran mayores. Igualmente, los antecedentes urbanos, los niveles superiores de instrucción, las profesiones de cuello blanco y los altos conocimientos lingüísticos tienen una incidencia positiva en la probabilidad de solicitar la ciudadanía.

Es difícil determinar si el nivel de distinción proveniente de las dos encuestas realizadas es el resultado de contextos históricos, sociales y económicos del proceso migratorio de los dos países o de características diferentes de las poblaciones inmigrantes turcas o una combinación de todos esos factores. Por ello, las conclusiones desconcertantes sobre la importancia de la duración de la residencia en la adquisición de la ciudadanía podrían, por ejemplo, deberse a esta complejidad. Aun cuando la distinción entre los dos casos es evidente, existe un patrón similar entre los inmigrantes tanto en Melbourne como en Estocolmo con respecto a la percepción y actitudes de su propia posición en el proceso de asentamiento y de acceso a la ciudadanía. El sentimiento de temporalidad es más evidente entre los turcos en Suecia que entre aquellos en Australia, pero para la gran mayoría en ambos países la cuestión de solicitar la ciudadanía es más bien una opción pragmática y no un compromiso normativo o de orden moral. 